\title{
Migration of Junior Doctors: The Case of Psychiatric Trainees in Portugal
}

\section{Migração dos Jovens Médicos: O Caso dos Internos de Psiquiatria em Portugal}

\author{
Mariana PINTO DA COSTA $\triangle^{1,2,3}$, Cátia MOREIRA4 ${ }^{4}$, Luís F. S. CASTRO-DE-ARAUJO ${ }^{5,6}$, Fábio Monteiro da SILVA ${ }^{1}$, \\ Renato Antunes dos SANTOS ${ }^{7}$
}

Acta Med Port 2021 Jul-Aug;34(7-8):533-540 • https://doi.org/10.20344/amp.12562

\section{ABSTRACT}

Introduction: In the last few decades, the rates of international medical migration have continuously risen. In Psychiatry, there is great disparity in the workforce between high and low-income countries. Yet, little is known about the 'push' and 'pull' factors and the migratory intentions of trainees. This study aims to assess the factors impacting the decisions of psychiatric trainees in Portugal towards migration.

Material and Methods: A questionnaire was developed in the Brain Drain study and was distributed to psychiatric trainees in Portugal. Results: The sample consists of 104 psychiatric trainees (60.6\% female). Overall, $40.4 \%$ of the trainees had prior experience of living abroad and the majority (96.9\%) felt that this experience influenced their attitude towards migration in a positive way. About $75 \%$ of trainees had 'ever' considered leaving the country, but the majority $(70.0 \%)$ had not taken any 'practical steps' towards migration. The main reasons to stay in Portugal were personal, while the main reason to leave was financial. The majority of the trainees (55.7\%) were dissatisfied or very dissatisfied with their income, working conditions and academic opportunities.

Discussion: Working conditions, salaries and academic opportunities are the main triggers for the migration of psychiatric trainees from Portugal.

Conclusion: These results may inform the decisions of stakeholders in the health and education sectors and point out the necessary investments required and the impact it may have on the workforce.

Keywords: Emigration and Immigration; Internship and Residency; Job Satisfaction; Motivation; Physicians; Portugal; Psychiatry; Workplace

\section{RESUMO}

Introdução: Nas últimas décadas, a migração médica internacional tem aumentado continuamente. Na Psiquiatria, existe uma grande disparidade de recursos humanos entre países desenvolvidos e com baixo desenvolvimento económico. No entanto, pouco se sabe sobre os fatores que atraem (push) ou afastam (pull) a mobilidade e quais as intenções migratórias dos internos de psiquiatria. $\mathrm{O}$ objetivo deste estudo é avaliar os fatores que influenciam o processo de tomada de decisão dos internos de Psiquiatria em Portugal relativamente à migração.

Material e Métodos: Um questionário foi desenvolvido no âmbito do estudo Brain Drain, e foi enviado aos internos de Psiquiatria em Portugal.

Resultados: A amostra é constituída por 104 internos de Psiquiatria (60,6\% do sexo feminino). No geral, 40,4\% dos internos tiveram uma experiência de mobilidade e a maioria $(96,9 \%)$ sentiu que esta os influenciou positivamente na sua atitude em relação à migração. Cerca de $75 \%$ dos internos já considerou emigrar, mas a maioria $(70,0 \%)$ não deu nenhum passo nessa direção. A principal razão para permanecer no país prende-se com factores pessoais, enquanto o principal motivo para emigrar é financeiro. A maioria (55,7\%) dos internos estava insatisfeito ou muito insatisfeito com o seu salário, condições de trabalho e oportunidades académicas.

Discussão: Condições de trabalho, salários e oportunidades académicas são os principais estímulos para a emigração nos internos de Psiquiatria em Portugal.

Conclusão: Estes resultados poderão apoiar a tomada de decisão dos decisores em saúde e educação médica sobre os investimentos necessários e a sua influência na força laboral futura.

Palavras-chave: Emigração e Imigração; Internato e Residência; Local de Trabalho; Médicos; Motivação; Portugal; Psiquiatria; Satisfação Profissional

\section{INTRODUCTION}

Worldwide migration has been growing rapidly and in 2017 the number of international migrants reached 258 million. ${ }^{1}$ Migration to affluent countries is not a recent phenomenon among health professionals. ${ }^{2}$ In the last few decades the rates of international medical migration have risen

continuously, creating new debates over professional opportunities in donor and host countries. ${ }^{3}$ Globalisation fuels migration and health workers are increasingly more mobile, connected and aware of the opportunities in other (more affluent) countries..$^{2,4,5}$

\footnotetext{
1. Psychiatry Department. Hospital de Magalhães Lemos. Porto. Portugal.

2. Institute of Biomedical Sciences Abel Salazar. University of Porto. Porto. Portugal.

3. Unit for Social and Community Psychiatry (WHO Collaborating Centre for Mental Health Services Development). Queen Mary University of London. London. United Kingdom.

4. Psychiatry Department. Centro Hospitalar Psiquiátrico de Lisboa. Lisboa. Portugal.

5. Centre of Data and Knowledge Integration for Health (CIDACS). Instituto Gonçalo Muniz. Fundação Osvaldo Cruz. Salvador. Brazil.

6. Department of Psychiatry. The University of Melbourne. Victoria. Australia.

7. Department of Psychiatry. Douglas Mental Health University Institute. McGill University. Montréal. Canada.

$\square$ Autor correspondente: Mariana Pinto da Costa. mariana.pintodacosta@gmail.com

Recebido: 16 de julho de 2019 - Aceite: 13 de dezembro de 2019 - First published: 11 de fevereiro de 2020 - Online issue published: 01 de julho de 2021

Copyright $\odot$ Ordem dos Médicos 2021
} 
Migration is influenced by many macro (environmental, social, economic, political) and micro (personal characteristics) factors that lead to cross-border movements. These are commonly referred to as 'push' and 'pull' factors. ${ }^{6} \mathrm{Mi}-$ gration trends are an important concern for policy makers in donor and host countries worldwide. As such, migratory movement of medical staff from low-income countries (LIC) leads to a shortage of staff in the country of origin. Countries in Africa, in particular, have voiced their concerns on migration of their physicians to high income countries (HIC). ${ }^{7}$ To address this important matter in the global health agenda, in 2010 the World Health Assembly adopted the World Health Organization (WHO) Global Code of Practice for the International Recruitment of Health Personnel. ${ }^{8}$ The code aims to address health professionals' migration from countries with a limited workforce, to comparatively wealthier countries. ${ }^{9}$

In Psychiatry, there is a great disparity in human resources between HIC and LIC. About $70 \%$ of the global mental health professional workforce is working in $\mathrm{HIC}$, with half of them working in Europe..$^{10}$ According to the WHO Mental Health Atlas, HIC had 6.6 psychiatrists per 100000 population in 2014 and this number increased to 11.9 psychiatrists per 100000 population in 2017 . On the other hand, in the same period, the proportion was stable at less than 0.1 per 100000 population in LIC. ${ }^{10,11}$

Portugal is a HIC and it was reported to have approximately 4.49 psychiatrists per 100000 population in $2014 .{ }^{11}$ Further to the creation of the European Community through the Treaty of Rome in 1957, in 1993 the borders started to become more permeable. Since then, the Portuguese (as other EU) citizens have had the freedom to move across borders within Europe. Some data has suggested that this balance has been negative to Portugal with few health workers moving to Portugal and more Portuguese moving abroad. ${ }^{12}$ However, little is known about the migratory intentions of junior doctors in Portugal, and their 'push' and 'pull' factors.

This paper aims to understand the patterns of migration of psychiatric trainees in Portugal, including previous mobility experiences, intentions for future migration and their push and pull factors.

\section{MATERIAL AND METHODS \\ Study design}

This cross-sectional survey was conducted as part of the EFPT Brain Drain study. ${ }^{13}$ Data from individual psychiatric trainees were collected through an anonymous semistructured self-administered questionnaire. The questionnaire consisted of 61 questions, covering demographics, experiences of short-term mobility (defined as lasting between three months and one year), experiences of longterm migration (defined as lasting more than one year) and attitudes towards migration. Migratory tendency was assessed in a hierarchical manner with three questions: 'ever' considered leaving, considering leaving 'now' and taking 'practical steps' towards migration. More information about the questionnaire can be retrieved elsewhere. ${ }^{13}$

\section{Data collection}

The questionnaire was written in English, as trainees were deemed to have adequate command of the language

Table 1 - Sample demographics $(n=104)$

\begin{tabular}{llc}
\hline Variables & & $\mathbf{n}(\%)$ \\
\hline Gender & Male & $36(34.6 \%)$ \\
& Female & $63(60.6 \%)$ \\
& NA & $4.8 \%)$ \\
Age & & Mean 28.7 [SD (2.38)] \\
Portugal nationals & & $101(97.1 \%)$ \\
Relationship status & In a relationship & $56(53.8 \%)$ \\
& Not in a relationship & $43(41.3 \%)$ \\
Have children & NA & $5(4.8 \%)$ \\
& No & $93(89.4 \%)$ \\
Type of trainee & Yes & $6(5.7 \%)$ \\
& NA & $5(4.8 \%)$ \\
Number of years of psychiatry training & Adult psychiatry & $95(91.3 \%)$ \\
& Child psychiatry & $9(8.7 \%)$ \\
& Year 1 & $28(26.9 \%)$ \\
& Year 2 & $18(17.3 \%)$ \\
& Year 3 & $22(21.15 \%)$ \\
& Year 4 & $18(17.3 \%)$ \\
\end{tabular}

NA: not available; SD: standard deviation 
to reliably answer the questions. The only inclusion criteria was that participants had to be psychiatric trainees, defined as a fully qualified medical doctor under the nationally recognised Psychiatry specialist training program in Portugal. According to official data from the Portuguese Health Central System Administration (ACSS) from 2011, there were 193 psychiatric trainees in Portugal. ${ }^{14}$ All participants were required to give informed consent before the assessment. Data was collected between 2013 and 2014.

The link of the questionnaire was either sent via e-mail to the national contact database mailing list of psychiatric trainees from the Portuguese Association of Psychiatric Trainees (APIP), or a printed copy of the questionnaire was given to psychiatric trainees during educational events. The survey was conducted according to the principles of good scientific practice, which was supported by a national ethics committee approval in Switzerland and approved by the Ethics Committee of beider Basel / EKBB beider Basel / EKBB (Request 144/13).

\section{Statistical analysis}

The statistical analyses were carried out using $R$ version 3.4.2 (https://cran.r-project.org/). Descriptive statistics consisted of frequencies and percentages. All variables from the dataset were categorical, except for age. Three Fisher's exact tests were performed with a significance level (alpha) of 0.05 comparing current plan to work abroad with the outcomes: previous migration, marital status and having children.

\section{RESULTS \\ Sample characteristics}

From all the psychiatric trainees in Portugal contacted ( $\mathrm{n}$ = 193), 104 trainees completed the survey (response rate of $53.9 \%$ ). Demographics are reported in Table 1. Most of the respondents were originally from one of the main cities in Portugal: Porto ( $n=25,24.0 \%)$, Lisbon $(n=18,17.3 \%)$ and Coimbra $(n=11,10.6 \%)$. At the time of the survey, the majority $(n=35,33.6 \%)$ were living in Lisbon (Table 1).

\section{Previous short-mobility and long-term migration expe- riences}

In this study, about one third of psychiatric trainees in Portugal ( $n=37,30.6 \%$ ) reported previous short-term mobility experiences, although only a few $(n=10,8.3 \%)$ had a previous experience of long-term migration. Many of the trainees ( $n=42,40.4 \%$ ) already had an experience abroad, either short or long-term, with five respondents having had both short and long-term experiences.

Among those with a short-term mobility experience, the

What reasons make you stay in the country you currently live in?

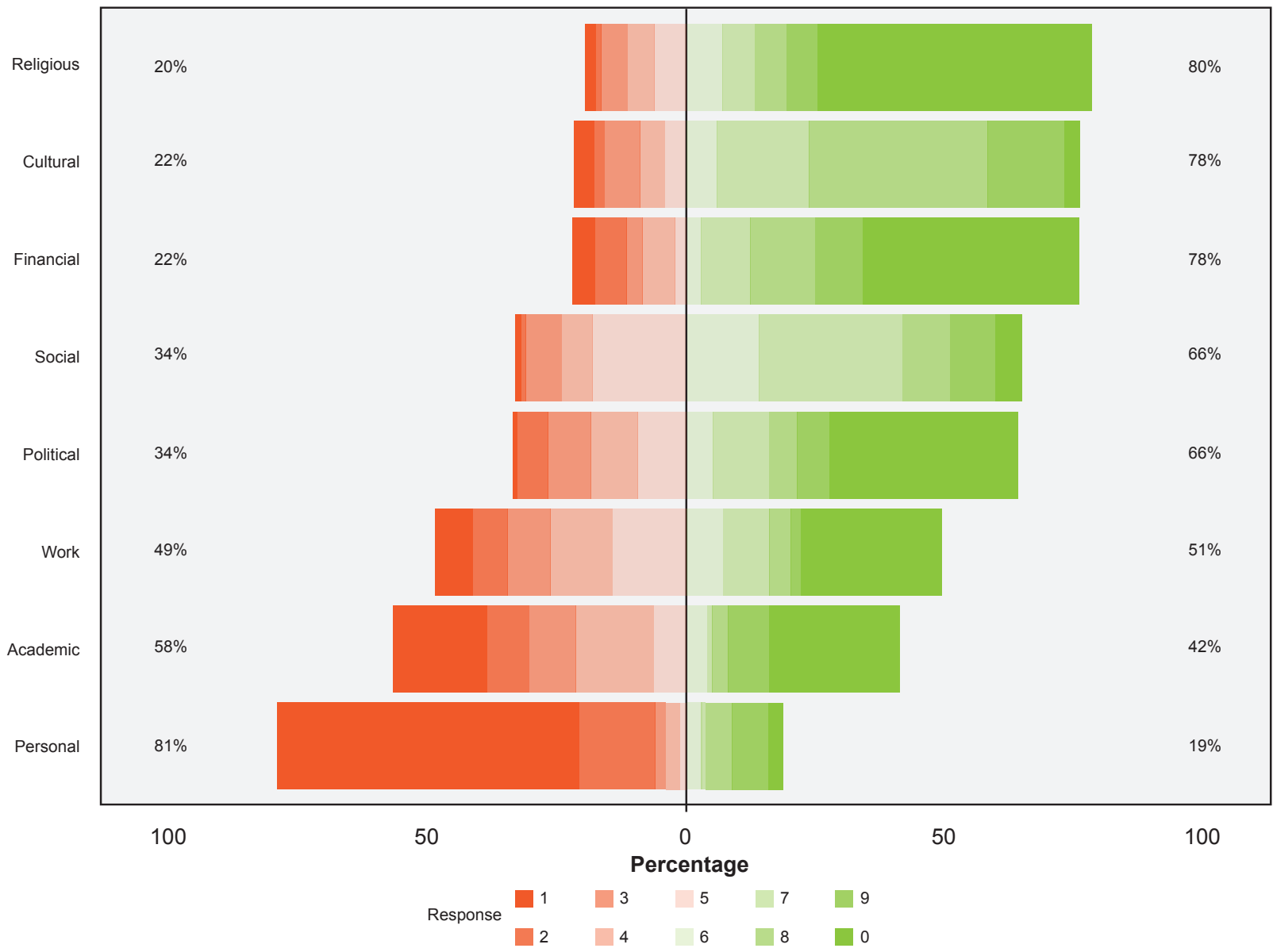

Figure 1 - Reasons to stay in the country 
For what reasons would you leave the country you currently live in?

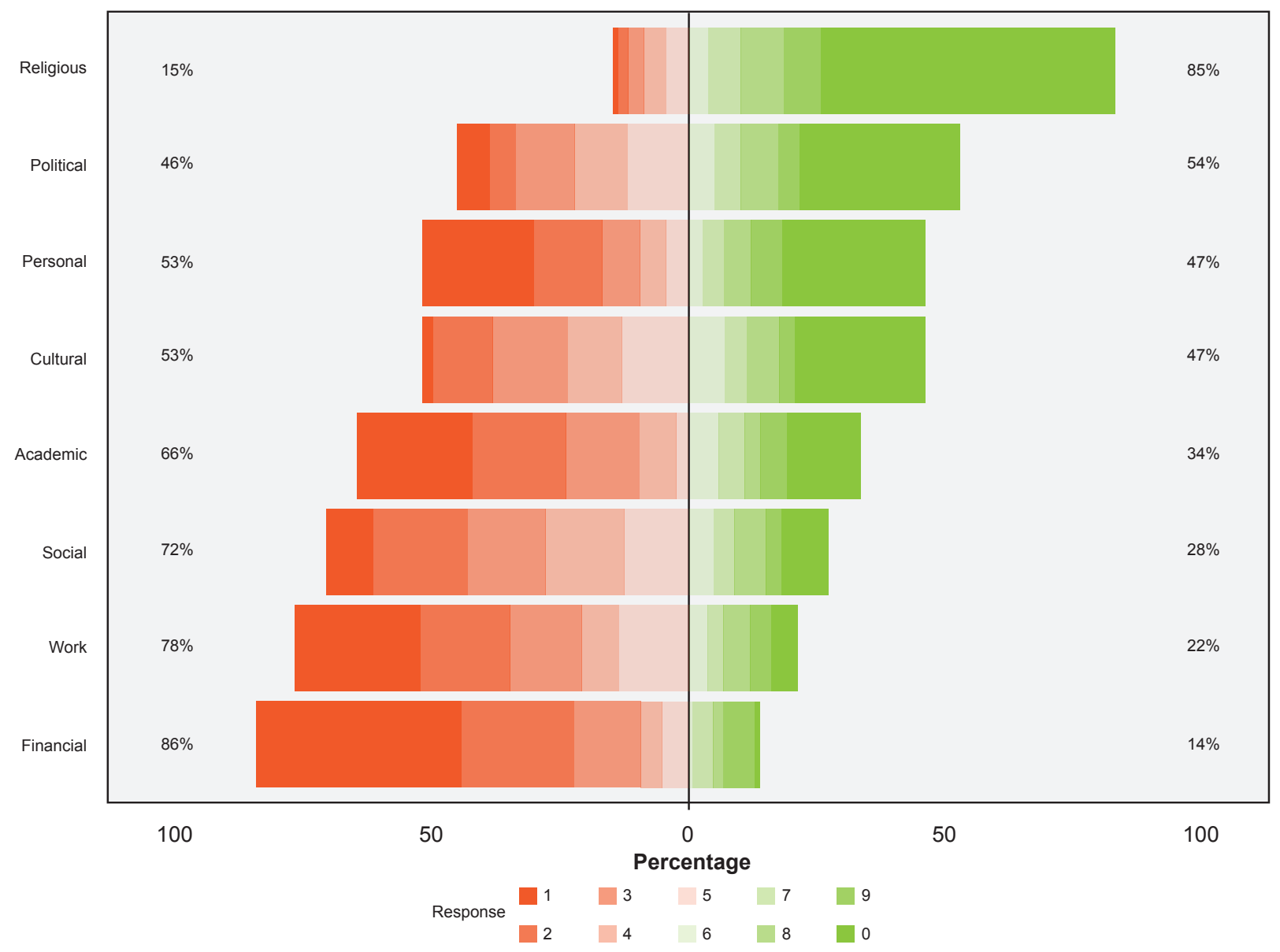

Figure 2 - Reasons to leave the country

majority ( $n=32,86.5 \%)$ felt that this experience influenced their attitude towards migration, with the vast majority $(n=31,96.9 \%)$ in favour of migration. Only one person became less favourable to migration.

Among those with an experience of long-term migration ( $n=10)$, half $(n=5)$ migrated alone and the remainder moved with their partner $(n=1)$, parents $(n=2)$ or other family members $(n=2)$. Importantly, the majority $(n=7)$ considered having the same opportunities as local people, with only a few $(n=3)$ feeling that they had less opportunities. In this sample, female trainees migrated slightly more than male trainees (39.7\% vs $38.9 \%)$.

\section{Push and Pull Factors}

The main reasons to stay in Portugal ('push factors') were personal (e.g. health, partner, children, family) $(n=59$, $59.6 \%$ ), followed distantly by academic reasons (e.g. training or educational opportunities) $(n=18,18.5 \%)$. The main reasons to leave Portugal ('pull factors') were financial (e.g. salaries) $(n=40,40.8 \%)$, followed by work (e.g. employment conditions, workload) $(n=24,25.0 \%)$, academic $(n=$ $22,22.9 \%)$, and personal $(n=21,22.1 \%)$. Fig. 1 reports the main reasons to stay and Fig. 2 the main reasons to leave.

\section{Migratory tendencies}

More than two-thirds $(n=77,75.0 \%)$ of trainees had 'ever' considered leaving the country; nearly half of them $(n=38,49.0 \%)$ were considering leaving the country 'now' and about one-third $(n=19,30.0 \%)$ had already taken 'practical steps' towards migration.

When asked about their 5-year plan, nearly half $(n=51$, $50.0 \%$ ) of the trainees predicted to be in Portugal, while the rest thought they were going to be somewhere in Europe $(n=22,21.0 \%)$, anywhere in the world $(n=6,5.8 \%)$, or had not made up their mind yet $(n=13,13.0 \%)$.

We did not find any statistically significant association (Fisher's exact test) when comparing current plans to work abroad with previous migration ( $p=0.35$, two-tailed), marital status ( $p=0.2$, two-tailed) or having children $(p=0.82$, two-tailed) (Table 2).

Psychiatric trainees expressed the following aspects should be improved in the Psychiatry profession in Portugal: working conditions (e.g. working hours) $(n=96,92.3 \%)$, financial support (e.g. salaries) $(n=91,88 \%)$, academic conditions (e.g. training or educational opportunities) $(n=64$, $61.5 \%$ ) and professional networking (e.g. team work, cooperation) ( $n=51,49.0 \%)$. The factors that make a job attractive for psychiatric trainees in Portugal included a pleasant working environment, a high salary and the possibility of 
Table 2 - Plans to work abroad, previous migration experience and marital status

\begin{tabular}{|c|c|c|c|}
\hline \multicolumn{3}{|c|}{ Previous Migration n (\%) } & \multirow[t]{2}{*}{ Fisher's exact test } \\
\hline Plans to work abroad & No & Yes & \\
\hline Yes & $7(39 \%)$ & $11(61 \%)$ & \multirow{3}{*}{$p=0.35$} \\
\hline No & $8(62 \%)$ & $5(38 \%)$ & \\
\hline "I don't know yet" & $26(57 \%)$ & $20(43 \%)$ & \\
\hline \multicolumn{3}{|c|}{ Marital status n (\%) } & \\
\hline Plans to work abroad & In a relationship & Not in a relationship & \\
\hline Yes & $11(65 \%)$ & $6(35 \%)$ & \multirow{3}{*}{$p=0.20$} \\
\hline No & $4(33 \%)$ & $8(67 \%)$ & \\
\hline "I don't know yet" & $27(61 \%)$ & $17(39 \%)$ & \\
\hline \multicolumn{3}{|c|}{ Children n (\%) } & \\
\hline Plans to work abroad & No & Yes & \\
\hline Yes & $16(94.1 \%)$ & $1(5.9 \%)$ & \multirow{3}{*}{$p=0.82$} \\
\hline No & $12(100 \%)$ & $0(0 \%)$ & \\
\hline "I don't know yet" & $40(90.4 \%)$ & $4(9.1 \%)$ & \\
\hline
\end{tabular}

* six person who had migratory experience did not answer the question about plans to work abroad

The following features make any job attractive to me:

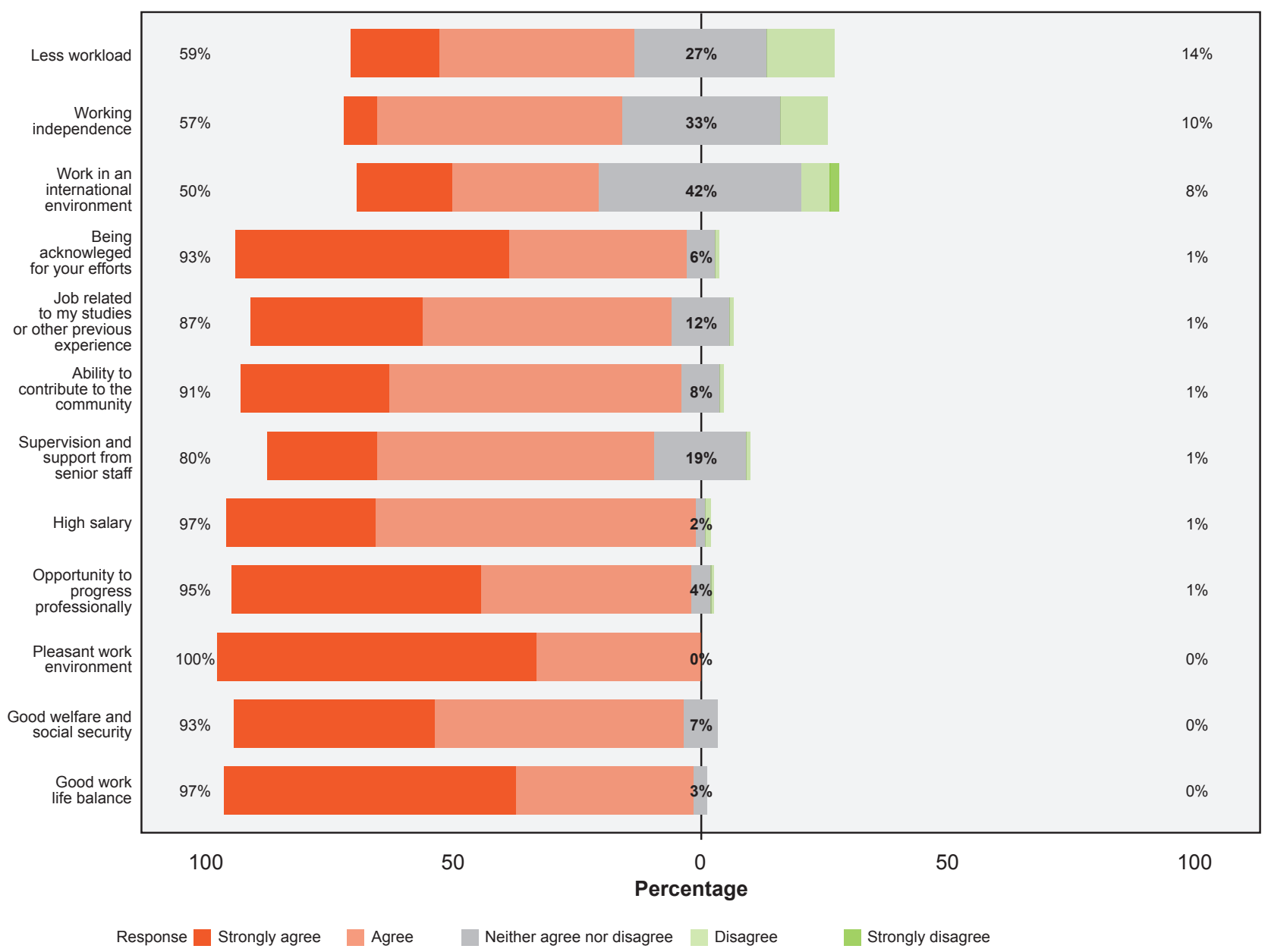

Figure 3 - Features of an attractive job

managing a positive work-life balance (Fig. 3).

The monthly income for the majority $(n=88,84.6 \%)$ of psychiatric trainees was between $1000 €$ and $1499 €$, with about one-fourth ( $n=25,24.0 \%$ ) earning additional income. 
Importantly, the majority of trainees were dissatisfied or very dissatisfied with their income $(n=58,55.7 \%)$, about one fourth ( $n=29,27.9 \%$ ) were neither satisfied nor dissatisfied $(n=29,27.9 \%)$ and only a few $(n=12,11.5 \%)$ were satisfied or very satisfied.

\section{DISCUSSION \\ Key results}

An important proportion of trainees in Portugal (40.4\%) had previous experience of short-term mobility or long-term migration. Furthermore, three quarters of the trainees had 'ever' considered leaving the country and almost half are considering leaving the country 'now'. Importantly, the majority of trainees were dissatisfied or very dissatisfied with their income.

\section{Comparison with the literature}

It is not uncommon for trainees in Portugal to have short-term international mobility experiences during their training, and for their salary to be paid for by the Portuguese government while they are rotating abroad. Portuguese citizens (like from other EU countries) have the freedom to move across borders within Europe, possibly explaining such a high number of trainees with previous short-term mobility experiences. Compared to Turkey, trainees in Portugal had higher rates of both short-term mobility $(30.6 \%$ vs $13.1 \%)$ and long-term migration experiences $(8.3 \%$ vs $4.7 \%){ }^{15}$

In comparison to the overall European results from this study, ${ }^{13}$ trainees in Portugal with previous short-mobility experiences were generally satisfied with their experiences abroad and had a positive attitude towards future migration. Equally, the same rates of trainees in Portugal (as in Europe overall) had 'ever' considered leaving the country and were considering leaving the country 'now'. A higher rate (onethird) in Portugal had taken practical steps towards migration compared to the European results (one-fourth).

Among trainees in Portugal, the most important push factor is by far personal reasons, such as health or having a partner or children (59.6\%), which was similar to the main push factor in Romania. ${ }^{16}$

Whereas for the pull factors, financial reasons were considered one of the main reasons to leave Portugal. It should be noted that although a HIC, Portugal is among the European countries where psychiatric trainees are paid the worst, after the Eastern European countries. ${ }^{13}$ This may explain why the majority of the psychiatric trainees were dissatisfied or very dissatisfied with their income. Financial reasons were also the top reason to leave the country in Romania and Turkey. ${ }^{15,16}$ However, trainees in Romania considered social factors as the second most important pull factor, while this reason was mentioned by fewer trainees in Portugal. ${ }^{16}$ As for the conditions that should be improved in the Psychiatry profession, the main three were: working conditions, financial and academic conditions. In other countries such as Turkey, trainees expressed the same recommendations but in a different order of priority. ${ }^{15}$

\section{Strengths and limitations}

To the best of our knowledge, this is the only study on migration trends of psychiatric trainees in Portugal. The response rate of more than half is another of its strengths, as well as the characteristics of the sample (with the majority being female) which is in line with the population of psychiatric trainees in Portugal ${ }^{14}$ and in Europe. ${ }^{13}$ Currently, at least $60 \%$ of new graduates and $30 \%$ of the medical workforce are women, ${ }^{9}$ and there is an increasing number of female psychiatrists in various countries. ${ }^{17,18}$

However, some limitations should be noted. A self-report questionnaire is subject to recall and reporting bias, as well as social desirability bias. Moreover, there may also have been a selection bias, where trainees that were keener in migrating may have been more prone to respond to this survey, which could lead to potential higher rates of positive attitudes towards migration. In addition, as the survey was circulated in English, it could be the case that trainees who are fluent in English could be more interested in migration.

Still, this study only focused on trainees who are currently training in Portugal, and Portuguese junior doctors who have emigrated were not included in this sample. These could either be the case of junior doctors who are currently training in other countries or specialists who after finishing their training in Portugal, have already migrated to other countries. Future studies should explore the push and pull factors among psychiatrists and psychiatric trainees who are currently emigrated to further understand the reasons to migrate in those that have moved country already.

Of note, our findings refer to different types of migratory tendencies ('ever', 'now' and 'practical steps'), and it is unclear which parameter optimally assesses the intention to migrate. Future studies should explore the actual migratory flows of these doctors, checking where they have migrated and how many times. In order to ensure accuracy, efforts should be made to harmonise definitions of migration as well as mechanisms of data collection. This is also to facilitate the comparison of migration statistics across countries on data that is already routinely collected for administrative purposes. ${ }^{19}$

Finally, as the sample size is small, it is not possible to explore possible sub-groups and the impact of individual characteristics in the intention to migrate in Portugal.

\section{Relevance of the findings and implications for practice, policies and research}

This study provides valuable data on previous, current and future international migration tendencies among psychiatric trainees in Portugal, as well as their reasons for migrating or remaining in the country. These findings can assist decision-makers in implementing strategies to promote stability in the country's medical workforce, while recognising doctors as autonomous people with rights.

Our findings suggest that in order to maintain a stable health workforce, policy-makers must improve working, financial and academic conditions. Tackling salaries and academic conditions (e.g. addressing doctor's reasons for 
leave or encouraging them to return) might help modulate these 'pull factors' and provide countries with the tools to improve training conditions and address migration caused by training dissatisfaction.

Wage adjustment, while an important factor, in Portugal is not at the reach of managers at an institutional level. Therefore, the focus could be on improving working and academic conditions, providing financial support to attend congresses and courses, and providing opportunities for continuous professional development. The authors suggest the creation of a special interest day for psychiatry training in Portugal, which would provide dedicated time for trainees to conduct activities of their own interest, such as research or psychotherapy, that otherwise trainees may not have time to pursue during their mandatory rotations. Such 'special interest days' are popular in countries such as the UK, with a positive impact in the trainees' development ${ }^{20}$.

Furthermore, the standardisation of psychiatry training curricula, could be an important step to empower psychiatrists and to make them capable of transferring their skills into different social and cultural situations, ensuring that the essential core knowledge for practicing psychiatry in all contexts is acquired.

In this study, the majority of the results relate to the intention to migrate in the future, rather than the current migratory movements. Following up these respondents will help gauge migratory intentions, which can be extended to predict current migration.

Given that the number of psychiatric trainees has increased in Portugal in the last few years, it would be important to repeat this study, and assess whether the wishes and trends for migration in psychiatric trainees in Portugal attenuate or alleviate in the upcoming future.

Additionally, as it is uncertain how specific these results are to psychiatric trainees in Portugal, future studies should explore whether the findings differ for junior doctors in other medical specialties or psychiatry specialists in Europe.

Further studies concerning physicians that migrated already, as well as studies looking at to what extent have the trainees considering leaving the country materialised their intentions should be conducted. That could relay the message to health managers that the time to make changes is now.

\section{REFERENCES}

1. United Nations, Department of Economic and Social Affairs. un.org [homepage na Internet]. [accessed 2019 Jan 27]. Available from: http:// www.un.org/en/development/desa/population/migration/publications/ migrationreport/docs/MigrationReport2017_Highlights.pdf.

2. Bhagwati J, Hamada KJ. The brain drain, international integration of markets for professionals and unemployment: a theoretical analysis. J Dev Econ. 1974;1:19-42.

3. Epstein RJ, Epstein SD. Modernising the regulation of medical migration: moving from national monopolies to international markets. BMC Med Ethics. 2012;13:21.

4. Clark PF, Stewart JB, Clark DA. The globalization of the labour market for health-care professionals. Int Labour Rev. 2006;145:37-64.

5. Fried BJ, Harris DM. Managing healthcare services in the global marketplace. Front Health Serv Manage. 2007;24:3-18.

\section{CONCLUSION}

Many psychiatric trainees in Portugal have considered migrating abroad. The three main pull factors for migration of psychiatric trainees in Portugal are: working conditions, remuneration, and academic; while the majority of psychiatric trainees in Portugal are dissatisfied with their income. By addressing these important factors, stakeholders in the health and medical education sector may contribute to stabilise the Psychiatry workforce in Portugal.

\section{AUTHORS CONTRIBUTION}

MPC: Designed the study, coordinated and supervised the study group, the statistical analysis and drafted the manuscript.

CM: Helped drafting the manuscript.

LFSCA: Conducted the statistical analysis.

FMS: Helped drafting the manuscript.

RAS: Helped drafting the manuscript.

\section{ACKNOWLEDGEMENTS}

The authors would like to thank the European Federation of Psychiatric Trainees (EFPT) and the Portuguese Association of Psychiatric Trainees (APIP) for their support to this research project. We are grateful to Kirat Virdi who as a native speaker provided language editing to the final version of this article.

\section{PROTECTION OF HUMANS AND ANIMALS}

The authors declare that the procedures were followed according to the regulations established by the Clinical Research and Ethics Committee and to the Helsinki Declaration of the World Medical Association.

\section{DATA CONFIDENTIALITY}

The authors declare having followed the protocols in use at their working center regarding participants' data publication.

\section{COMPETING INTERESTS}

The authors have declared that no competing interests exist.

\section{FUNDING SOURCES}

None.

6. Mullan F. The metrics of the physician brain drain. $\mathrm{N}$ Engl $\mathrm{J}$ Med. 2005;353:1810-8.

7. Bundred P, Levitt C. Medical migration: who are the real losers? Lancet. 2000;356:245-6.

8. World Health Organization. Code of Practice for the International Recruitment of Health Personnel. Geneva: WHO; 2010.

9. Wismar M, Maier C, Glinos I, Dussault G, Figueras J. Health professional mobility and health systems. Evidence from 17 European countries. København: WHO Regional Office for Europe; 2011.

10. World Health Organization. Mental health atlas 2017. Geneva: WHO; 2018.

11. World Health Organization. Mental health atlas 2014. Geneva: WHO; 2015.

12. Ribeiro J, Conceicao C, Pereira J, Leone C, Mendonca P, Temido M, et 
al. Health professionals moving to... and from Portugal. Health Policy. 2014;114:97-108.

13. Pinto da Costa M, Giurgiuca A, Holmes K, Biskup E, Mogren T, Tomori S, et al. To which countries do European psychiatric trainees want to move to and why? Eur Psychiatry. 2017;45:174-81.

14. Pinto da Costa M, Guerra C, Malta R, Moura M, Carvalho S, Mendonca D. Psychiatry training towards a global future: trainees' perspective in Portugal. Acta Med Port. 2013;26:357-60.

15. Kilic O, Sonmez E, Erzin G, Guloksuz S, Pinto da Costa M. Mobility trends of psychiatric trainees in Turkey: hard to leave, harder to stay? Eur Arch Psychiatry Clin Neurosci. 2018;269:367-9.

16. Giurgiuca A, Rosca A, Matei V, Giurgi-Oncu C, Zgarbura R, Szalontay
A, et al. European Union mobility, income and brain drain. The attitudes towards migration of Romanian psychiatric trainees. Rev Cercet Interv So. $2018 ; 63: 268-78$.

17. Sood M, Chadda RK. Women psychiatrists in India: a reflection of their contributions. Indian J Psychiatry. 2010;52:S396-401.

18. Kim HK, Kim SI. Significance in the increase of women psychiatrists in Korea. Seishin Shinkeigaku Zasshi. 2008;110:558-62.

19. Stilwell B, Diallo K, Zurn P, Dal Poz M, Adams O, Buchan J. Developing evidence-based ethical policies on the migration of health workers: conceptual and practical challenges. Hum Resour Health. 2003;1:8.

20. Christodoulou N, Kasiakogia K. Psychiatry training in the United Kingdom - Part 2: the training process. Psychiatriki. 2015;26:55-60. 